\title{
A STUDY ON THE LITERACY-RICH CLASSROOM ENVIRONMENT AT BILINGUAL KINDERGARTEN SINGARAJA BALI
}

Pratiwi, N.M.R.H. English Education Department, Ganesha University of Education e-mail: restyhygar@gmail.com

Padmadewi, N.N. English Education Department, Ganesha University of Education e-mail: nym.padmadewi@undiksha.ac.id

Paramartha, A.A.G.Y. English Education Department, Ganesha University of Education e-mail: yudha.paramartha@undiksha.ac.id

\begin{abstract}
This study was observational case study that examined the components of literacy-rich classroom environment at Aura Sukma Insani Kindergarten. The subjects of the research were the students and the teacher of B1 class of Aura Sukma Insani Kindergarten. The study examined the components of literacy-rich classroom environment and how it was exposed to the students during teaching and learning process. The instruments in this study consisted of researcher, observation sheet, interview guide, and literacy-rich classroom environment checklist. The results indicate that the Aura Sukma Insani Kindergarten applied all elements of classroom literacy environment, namely; classroom setup, classroom library, message center, display of students' work, storytelling chair, sign, label, and quotes, hints, writing equipment, reading and writing corner, reference materials, audiovisual equipment, and dramatic center. The Aura Sukma Insani Kindergarten also used several activities to expose the literacy-rich classroom environment materials, namely; checking the students' attendance using present board, setting day, date, and month on calendar board, using the printed media and classroom equipment during the learning process, and rewarding students' achievement using students' sticker collection and toys, reading log, book week, follow-up activity, and after-hours session class. However, the after-hours session activity that used in learning process was found less-effective due to the time and the management of the activity.
\end{abstract}

Keywords: kindergarten education, literacy components, literacy-rich environment

\section{INTRODUCTION}

In this 21 st century, every country in the world is challenged to create a qualified and successful generation in which people are demanded to possess a variety of knowledge and skills. Shared decision-making, information sharing, collaboration, innovation, and speed are essential in today's enterprises (Adedokun, Parker, Henke, \& Burgess, 2017). Nowadays, success lies in being able to communicate, share, use the information to solve complex problems, and in being able to adapt to the changing 
circumstances. Hence, new standards for what students should be able to do are replacing the basic skill competencies and knowledge expectations of the past. To meet this challenge schools must be transformed in ways that will enable students to acquire creative thinking, flexible problem solving, collaboration and innovative skills they will need to be successful in work and life.

One of the transformations that can be done is by designing effective classroom environment for students. The classroom environment is a critical part of effective and successful teaching and learning process (Inan, 2009). Effective classroom environment, which initiates with well-organized and various materials and activities, helps students to learn. Hussain (2014), states that the classroom physical arrangement provides students with effective instruction and promotes smooth teaching-learning process. The well-organized classroom provides students with opportunities to socialize while learning interesting content. Students perform well in an optimistic classroom atmosphere and an environment in which they feel secure, safe, cared for and involved. According to Khoury (2011), a literacy-rich environment is one in which children interact with many different kinds of print, such as signs, labels, word walls, graphs, age-appropriate books, and other printed materials. Further, Kassow (2006), states that a literacy-rich classroom is a classroom in which print is seen in children's immediate surroundings and offers opportunities for them to view and engage many different forms of language. A literacy-rich environment is a setting that stimulates students to participate in language and literacy activities in their daily lives by giving them an understanding of the function of oral and written language.

Based on literature review, there are related theories. A literacy-rich environment is a context in which children engage in interest-based everyday literacy activities with responsive adults. According to Justice (2004), a rich language learning environment is one condition of language learning where children are exposed deliberately and recurrently to high-quality verbal input among students and teachers. Weaver (1990), states that a print-rich environment classroom is a classroom in which reading and writing are used for a wide variety of authentic, everyday purposes. Further, Kassow (2006) states that a print-rich environmental classroom is a classroom in which print is seen in children's immediate surroundings and offers opportunities for them to see and engage in many different forms of language.

According to Morrow ( as cited in Paratore \& McCormack, 2007) the purpose of a literacy-rich environment classroom as to create a literate print environment by integrating various kinds of print such as books, displays, magazines, etc. to connect students' understanding between written and spoken language. A literacy-rich environment is a setting that stimulates students to participate in language and literacy activities in their daily lives by giving them an understanding of the utility and function of oral and written language. Moreover, a literacy-rich environment provides students in special education courses access to the general education curriculum and provides teachers with information on why a literacy-rich environment is important and how to establish one (McGee \& Richgels, 1996).

The environment that is enriched by the target language helps to build the learners' critical thinking, and relationship skills (Archie, 2003). Students may have a discussion, sharing their ideas with their peers to do some hands-on activities. Besides that, he also stated that a literacy-rich environment helps students to get more opportunities to be familiar with the language. They can see the words and sentences around their environment. It would ease them to learn the language. Learning a 
language from their environment can motivate children to get a better achievement (Archie, 2003). In addition, Morrow and Weinstein (as cited in Neuman \& Dickinson 2003) state that the physical arrangement of a classroom can encourage children to spend more time with books. Also, the written language used for labels and signs in the natural environment promotes reading strategies for students. The exposure to print is the beginning of the process of learning to read and write that continues to emerge throughout the early childhood years (Paratore \& McCormack, 2007).

The condition of the class can be reflected in the application of language-rich classroom as described by Tompkins \& Hoskisson (as cited in Cahyaningtyas, 2017) as follows:

\section{Classroom Setup}

Benches are arranged in small groups which allow the student to interact with each other. Other class sections are designed into centralization for specific activities such as libraries, writing centers, and theme centers.

2. Classroom Library

At least there are books that can be read by all students in the class (ideally $4 x$ the number of students). The books include storybooks, information books, poetry, and other reading books. It can also display books collection of students' writing that related to the learning activity.

\section{Message Center}

Daily schedules and announcements are posted on separate boards, either announcement from school or student initiatives. Mailboxes can also be presented in the classroom so students can deliver their ideas/messages to their classmates.

\section{Display of Student Work}

All students at least display a work in the classroom. Students and teachers can decide which theme or work will be displayed. The theme can be changed every month or as agreed with the students. This can encourage students to produce good works and make them proud when their work can be displayed in the classroom.

5. Storytelling Chair

This storytelling chair is a particular chair that is used specifically for students who are reading his or her writings in front of his or her friends. The chairs can be designed face to the listeners.

6. Signs, labels, and quotes

Equipment in the class can be labeled according to their name and function, which the label is written by the students themselves. Students can also quote the words/proverbs they like to stick in the classroom.

\section{Hints}

Instructions are provided in the classroom to make it easier for students to find what they want to use. These instructions can be written by students or teachers.

8. Writing equipment

There are sections that can be used to place pencils, pens, papers, daily journals, notebooks, or even computers and other items that students can use during the learning activity. Students are allowed to use this equipment with rules clearly affixed on the classroom wall, such as having to report to the teacher if you want to borrow the equipment and return it in the first place.

9. Reading and Writing Corner

If the class is large enough, the teacher can provide a separate area for reading and writing. Or if the class is not sufficient for the procurement of this area, it can be 
made of the unused classroom or in the library. This area is expected to be conducive for students' reading and writing activities.

10. Reference materials

Teachers can set up special boards as a place to stick keywords related to learning materials. In addition, pictures, charts, books, media, and other references related to learning can also be displayed in the classroom.

11. Audiovisual equipment and materials

Audiovisual equipment such as LCD, tape, or radio can also be provided in the classroom (can also be in the closet if it is feared to be damaged). This equipment can be used to support learning activity that related to listening.

\section{Dramatic Center}

This area is a place of displaying equipment related to drama/storytelling activities such as dolls, puppets, drama script, etc. Then if the class will be used for storytelling activities, then there are some areas that are set as "stage".

\section{METHOD}

This study was observational case study using analytical induction method that examined the components of literacy-rich classroom environment at Aura Sukma Insani Kindergarten. The subjects of this study were the students and the teacher of B1 class Aura Sukma Insani Kindergarten. The object of this study was the components of literacy-rich classroom environment. The data were collected through observation and interview. There were 4 instruments to collect the data, such as; (1) researcher, (2) observation sheet, (3) interview guide, and (4) literacy-rich classroom checklist.. The data is analyzed by using Miles and Huberman model; (1) data collection, (2) data reduction, (3) data display, (4) conclusion drawing and verification.

\section{FINDING AND DISCUSSION}

\section{The components of literacy-rich classroom environment}

This study examined the components of classroom literacy environment in B1 class of Aura Sukma Insani Kindergarten through observation using the 12 components of classroom literacy environment presented by Tompkins \& Hoskisson (as cited in Cahyaningtyas, 2017). The results indicated that the B1 class of Aura Sukma Insani Kindergarten applied all the components of classroom literacy environment, as follows:

a. Classroom Setup

In B1 class of Aura Sukma Insani Kindergarten, the students sit on chairs in various seating arrangements. There were moveable benches and tables that can be arranged for students in varied shape such as u-shape and conventional depend on students' need. There are also mattresses in the classroom that are used by the students in learning activity.

b. Classroom Library

The book that were provided in the classroom library were the books that appropriate for kindergarten students such as BoBo magazine, story books, drawing and coloring books, alphabets, etc. Besides the variety of books, there were also students' worksheet folders that were placed in the classroom library. Students' worksheet folders were the compilation of students' work that compile in one type of colors with students' name on each folders.

c. Message Center 
There were two message centers that were placed outside the classroom close to teachers' office and temple. The first one was the message board for parents and guests. The board was placed on the outside of the classroom near the school's temple. The message board was used to put any information from the school. The second one was the message board for the school staff. The board itself was placed on the wall outside of the classroom near the teachers' office. The message board was used to put any information from the school to all of the school staff and as the present board for the staff.

d. Display of students' work

The students' drawings were displayed on the wooden board in the classroom. The wooden board was put higher than the height of the students, so all of the students can see their works displayed on the board. The students' works were displayed on the board in order to make the students feel appreciated for the works they have done in the classroom.

e. Storyteling Chair

In B1 class of Aura Sukma Insani Kindergarten, the teacher prepared a chair right in front of the class as storytelling chair. In retelling the story, the students sit on the storytelling chair so other students are able to see their performance. The students also accompanied by the teachers to help the students delivering the story.

f. Signs, Labels, and Quotes

There were many kinds of printed media that were relate with literacy that researcher found in the classroom such as sticker collection, alphabet, numbers, calendar, students' sticker collection, present board, and cutlery labels.

g. Hints

The hints that were used as the instruction for students during learning process were oral instructions. The oral instructions that the teacher gave to the students were depend on the activities that the students had. The instruction given to the students such as sit down please, open your book, put the pencil in the jar, please collect your paper, put your shoes neatly, etc.

h. Writing Equipment

The teacher in Aura Sukma Insani Kindergarten provided writing equipment for their students such as pencils, rubber, color makers, scissors, and crayons. Those utensils were used by the students to write or coloring activity.

i. Reading and Writing Corner

There was no specific space inside the classroom for reading and writing corner due to the size of the classroom and there was no spare room that can be used as reading and writing corner. Because of that, the students only use the classroom space as reading and writing corner. Inside the classroom there were moveable chairs and tables that usually arrange by the teacher for reading and writing activity.

j. Reference Materials

The teachers also provided a book shelf outside the classroom in order to help the students to maintain the reading habit even outside the classroom. The reference material shelf contains of reference materials or books that appropriate to the students age and needs such as story books, alphabet, number, animal, kids' songs, etc.

k. Audiovisual Equiment

In B1 class, there were $\mathrm{LCD}$, the screen projector, and speaker that was placed at the back of the classroom. Those equipments were used by the teacher to show the students videos or animations that related to the teaching and learning materials. 


\section{Dramatic Center}

Aura Sukma Insani Kindergarten does have a dramatic centre that is called Aura Sukma Insani Function Centre. The dramatic centre is put separately from the school area due to the space of the school that is impossible to have it inside the school.

Those learning material were used in teaching and learning activity of the students. One of the learning activities that the students had was literacy activity such as reading, speaking, writing, and listening. Those literacy media that available in the classroom can e used by the teacher to increase students' literacy skill such as arranging the chairs and tables in the classroom in learning oral instructions, using books that available at classroom library in practicing reading skill, using students' worksheet in practicing writing skill, and using storytelling chair in storytelling activity to practice speaking skill.

\section{The way literacy-rich classroom exposed to students in teaching and learning activities.}

Aura Sukma Insani used several classroom activities and literacy programs in exposing the literacy materials to the students. The classroom activities using the literacy materials in B1 class were checking the students' attendance using present board, setting day, date, and month on calendar board, using the printed media and classroom equipment during the learning process, and rewarding students' achievement using students' sticker collection and toys. The other way that the teacher used to expose the literacy materials to the students were through several programs namely; reading log, book week, follow-up activity, and after-hours session class.

The discussion of this study examined the components of classroom literacy environment in B1 class of Aura Sukma Insani Kindergarten through observation using the 12 components of classroom literacy environment presented by Tompkins \& Hoskisson (as cited in Cahyaningtyas, 2017). The results indicated that the B1 class of Aura Sukma Insani Kindergarten applied all the elements of classroom literacy environment. There were 12 elements of classroom literacy environment that can be found in B1 class, namely; classroom setup, classroom library, message center, display of students' work, storytelling chair, sign, label, and quotes, hints, writing equipment, reading and writing corner, reference materials, audiovisual equipment, and dramatic center. All of the literacy materials were used by the teacher and students during teaching and learning process in which it was very effective as the beginning in introducing literacy to kindergarten students. These findings were in accordance with the previous studies indicating that literacy environment of a kindergarten classroom that rich of print display, books, writing and reading areas improved students' interest and increase students' literacy development during classroom activities (Khoury, 2011 \& Tarim, 2015).

Besides the 12 components of classroom literacy environment, this study also examined how the literacy materials were exposed to the students through observation and interview. The results indicated that Aura Sukma Insani had several classroom activities and literacy programs in exposing the literacy materials to the students. The classroom activities using the literacy materials in B1 class were checking the students' attendance using present board, setting day, date, and month on calendar board, using the printed media and classroom equipment during the learning process, and rewarding students' achievement using students' sticker collection and toys. The other way that the teacher used to expose the literacy materials to the students were through several 
programs namely; reading log, book week, follow-up activity, and after-hours session class. These findings were in line with the theory presented by Bird and Goodman (as cited in Philomena, 2018), teachers should ensure that learners have access to a variety of resources by providing many choices of literacy materials and activities.

One of the activities that held by Aura Sukma Insani Kindergarten that add powerful support to students' early literacy experiences is after-hours session class. The after-hours session activity focuses on increasing students' skill in literacy namely reading and writing. This activity gives students more early literacy experiences and chances to learn and train their reading and writing skill. Besides that, by having the activity that held separately from other school activity makes the students are able to focus only in reading and writing. This finding was in accordance with the theory presented by College (2014), kindergarten education plays a critical and significant role in promoting literacy, preventing reading difficulties, and preparing young children for the next stage of education. In this stage, children are introduced to numbers and letters as an early form of literacy before they start learning to read.

However, the after-hours session program that applied in B1 class was found less-effective than other activities due to its application such as the time of the activity and the management during the activity. As explained in the findings, the after-hours session class is held twice a week that is on Tuesday and Thursday which is start from 1 $\mathrm{pm}$ to $2 \mathrm{pm}$. Considering the time of the activity, it was held on the afternoon in which the focus of the students were not as good as they were in the morning. Besides that, kindergarten students are known to have short span of attention. According to Slattery and Willis (as cited in Juhana, 2014), young learners have a quite short attention span and are easy to get bored. These findings suggest that the schedule of the after-hours session class can be re-arranged so the students can be more focus in teaching and learning process.

In addition to after-hours session activity, the teaching and learning process during the activity was done by calling the students' name alternately and teach them one by one. The after-hours session activity in B1 class was handled by 3 teachers. Considering the amount of the students, there are 28 students in B1 class and it was difficult to monitor other students while all the teachers training the students' reading and writing one by one. Besides, there was no activity that given to the students as they were waiting for their turn. Students were found only sit on their chair and wait for the teacher to call their name alternately to practice their reading and writing with the teacher. According to Juhana (2014), teaching methods given to students must be enjoyable and interesting in order to maintain their interest in learning since children are easy to be bored. Based on these findings, it may be suggested that in order to be able in monitoring all the students, the teaching and learning process could be done together with all of the students and the face-to-face lesson only give when the students need more lesson or by giving the other students an activity or exercise while they are waiting for their turn so the students will not get bored.

\section{CONCLUSION}

Based on the result of this study, literacy materials and literacy activities play an important role in giving early literacy experience for the kindergarten students. Roskos and Neuman (as cited in (Moon \& Reifel, 2008) state that literacy props in the literacyrich classroom such as books, markers, and signs in a dramatic play center, etc can increase print awareness and engage students in more literacy-related activities such as 
reading and writing. Besides that, the appopriate literacy activities and program as the way to expose the literacy materials is needed since the students have quite short span of attention and they are in early stage of formal education where they first learn about literacy. It is supported by the theory presented by College (2014), kindergarten education plays a critical and significant role in promoting literacy and preparing young children for the next stage of education.

Although this study provided information on the current literacy environment of private kindergarten classroom in Singaraja, due to the small sample size, the result should not be generalized to the large population. Future research should be conducted with larger sample to compare the kindergarten classroom literacy-rich environment in different area. Furthermore, this study examined the physical component of literacy-rich classroom environment, future studies need to look at the psychological aspect of literacy-rich environment such as the teachers and students interaction related to literacy development during the classroom activities. Experimental studies are also needed to examine the effects of literacy-rich anvironment on students' literacy growth.

\section{REFERENCES}

Adedokun, O. A., Parker, L. C., Henke, J. N., \& Burgess, W. D. (2017). Student Perceptions of a 21st Century Learning Space. Journal of Learning Spaces, 6(1), 1-13. Retrieved August 25, 2018, from https://files.eric.ed.gov/fulltext/EJ1152589.pdf

Archie, M. L. (2003). Advancing Education Through Envronmental Literacy. Alexandria: Association for Supervision and Curriculum Development.

Artini, L. P. (2017). Rich Language Learning Environment and Young Learners' Literacy Skills in English. Lingua Cultura, 11(1), 19-24. Retrieved July 12, 2018, from http://journal.binus.ac.id/index.php/Lingua/article/view/1587

Bogdan, R. C., \& Biklen, S. K. (2007). Qualitatif Research for Education. An Introduction to Theory and Methods. Boston: Pearson.

Cahyaningtyas, A. P. (2017). Language-Rich Classroom Sebagai Perwujudan Sarana yang Mendukung Gerakan Literasi di Sekolah Dasar. Prosiding Seminar Nasional, (pp. 85-92). Semarang. Retrieved August 24, 2018, from http://pgsd.umk.ac.id/files/prosiding/2017/10\%20Andarini\%20Unissula.pdf

College, C. S. (2014). Language and Literacy Development in the Early Years:Foundational Skills that Support Emergent Readers. Language and Literacy Development in the Early Years, 24, 35-49. Retrieved August 26, 2018, from https://files.eric.ed.gov/fulltext/EJ1034914.pdf

Creswell, J. W. (2008). Educational Research. Planning, Conducting, and Evaluating Quantitative and Qualtative Research. Boston: Pearson.

Hussain, Q. S. (2014). Effects of Classroom Physical Environment on the Academic Achievement Scores of Secondary School Students in Kohat Division, Pakistan. International Journal of Learning \& Development, 4(1), 71-82. Retrieved July 8, 2018, from http://dx.doi.org/10.5296/ijld.v4i1.5174

Inan, H. Z. (2009). Understanding Features of Amiable Environments That Can Enourish Emergent Literacy Skills of Preschoolers. Australian Journal of Basic and Applied Sciences, 3(3), 2510-2518. Retrieved August 25, 2018, from http://ajbasweb.com/old/ajbas/2009/2510-2518.pdf 
Juhana. (2014). Teaching English to Young Learner: Some Points to be Considered. Asian Journal of Education and E-learning, 2(1), 43-46. Retrieved July 10, 2018, from https://www.ajouronline.com/index.php/AJEEL/article/download/575/470

Justice, L. M. (2004). Creating Language Rich Preschool Classroom Environment. Teaching Exceptional Children, 37(2), 36-44.

Kassow, D. Z. (2006). Environmental Print Awareness in Young Children. Talaris Research Institue, 1(3), 1-8. Retrieved July 10, 2018, from http://www.talaris.org/wp-content/uploads/EnviroPrintAwareness1.pdf

Keçia, V. (2016). The Positive Effects of Preschool Education in the Socialization and Learning of Children. Sociology Study, 6(2), 140-145. Retrieved August 26, 2018 , from http://www.davidpublisher.com/Public/uploads/Contribute/577df5bbd500c.pdf

Kekare, S. H. (2015). Classroom Physical Environment and Academic Achievement of Students. The International Journal of Indian Psychology, 2(3), 177-120. Retrieved June 20, 2018, from http://oaji.net/articles/2015/1170-1429886904.pdf Khoury, M. N. (2011). The Effect Of Rich Literacy Environment On Students' Motivation. Lebanese American University, America. Retrieved July 10, 2018, from https://laur.lau.edu.lb:8443/xmlui/bitstream/handle/10725/1022/Maya_Nabil\%2 0_El_Khoury_Thesis.pdf?sequence=1

McGee, L. \&. (1996). Literacy Beginnings: Support Young Readers and Writers. Needham Height, United States of America: A Simon \& Schuster Company.

Moon, K., \& Reifel, S. (2008). Play and Literacy Learning in a Diverse Language PreKindergarten Classroom. Contemporary Issues in Early Childhood, 9(1), 49-65. Retrieved August 26, 2018, from http://journals.sagepub.com/doi/pdf/10.2304/ciec.2008.9.1.49

Neuman, S. B. (2003). Handbook of early literacy research. New York: Guilford Press.

Padmadewi, N. N. (2016). Techniques of Promoting Autoomous Learning in The Classroom. Journal f Education and Social Sciences, 3, 45-52. Retrieved July 12, 2018, from http://jesoc.com/wp-content/uploads/2016/03/KC3_65.pdf

Paratore, J. R., \& McCormack, R. L. (2007). Classroom literacy assessment : making sense of what students know and do. New York: The Guilford Press. Retrieved August 20, 2018, from https://epdf.tips/download/classroom-literacyassessment-making-sense-of-what-students-know-and-do-solving.html?reader $=1$

Philomena, D. C. (2018). The Occupied Child and Engaged Teaching: Environmental Qualities Supporting Emergent Reading In Kenya. International Journal of Education and Research, 6(1), 87-100. Retrieved August 10, 2018, from http://www.ijern.com/journal/2018/January-2018/08.pdf

Pondika, N. L., Artini, L. P., \& Marhaeni, A. A. (2013). Developing Rich Language Learning Environment Material To Support Literacy Skills Of The Fourth Grade Students Of Primary Schools In Bali Province. e-Journal Program Pascasarjana Universitas Pendidikan Ganesha, 1. Retrieved June 8, 2018, from https://media.neliti.com/media/publications/118038-EN-developing-richlanguage-learning-enviro.pdf

Stroud, J. E. (1995). Block play: Building a foundation for literacy. Early Childhood Education Journal, 23(1), 9-13. Retrieved August 26, 2018, from https://link.springer.com/article/10.1007/BF02353373 
Sugiyono. (2008). Metode Penelitian Kualitatif, Kuantitatif, dan R \& D. Bandung: Alfabeta.

Susanto, A. (2011). Perkembangan Anak Usia Dini. Jakarta: Kencana.

Tarım, Ş. D. (2015). Literacy Environment of Preschool Education Classrooms in Turkey: The case of Mugla. Journal of Education and Training Studies, 3(5), 264-271. Retrieved July 10, 2018

Weaver, C. (1990). Understanding Whole Language: From principles to practice. Portsmouth: NH: Heinemann. Retrieved June 4, 2018, from http://www.sil.org/lingualinks/literacy/ReferenceMaterials/cGlossaryOfLiteracy Terms/WhatIsAPrintRichEnvironment.htm 